J. David Richardson is a professor of economics, The Maxwell School, Syracuse University and visiting fellow, Institute for International Economics. Copyright. Institute for International Economics, 2000. All rights reserved.

\section{The WTO and}

Market-Supportive Regulation:

\section{A Way Forward on New Competition, Technological and Labor Issues}

\section{J. David Richardson}

n this paper I argue that certain of the "new issues" in global trade negotiations belong there quite naturally. I label these conformable issues "marketsupportive regulation." I believe that wise incorporation of market-supportive regulation into the World Trade Organization (WTO) is the key to generating a new wave of "gains from trade"-and to widely disseminating those gains within and among societies.

I call this my thesis, for lack of an accurate, but humbler, term. My illustrations of market-supportive regulation include a subset of principles and practices from the domains of competition policies, technology policies, and labor-relations policies.

...But only a subset. Only those regulatory principles that conform most closely to the market system belong on the WTO negotiating agenda. The rest would hold back its progress.

My thesis begs several questions.

Why the title's emphasis on "a way forward" in WTO negotiations? Obviously because forward momentum is slow, and was slow even before the Seattle debacle. ${ }^{1}$ Less obviously, because it's still worth going forward for all WTO members, including the United States. Last and least obviously, because going forward on three specific new issues has unappreciated value. It is a way to do two urgently needed things: To further empower the global market system and, simultaneously, to increase its constituency and thus enhance its broad legitimacy.
What "privileges" the market system to lead me to recommend its further empowerment? First, I will argue that it is a remarkable social mechanism for reaching objectives of all kinds - necessary and noble, individual and communal, monetary and intangiblenoncoercively. Second, and more important, I believe that the current market system needs an incentive to negotiate on issues of its own legitimacy, limits, and regulation. Its gains from negotiating new issues, standing side-by-side with procedural and material gains for labor unions, technology users, and nascent and small firms, are what make my proposed way forward viable- because it is mutually beneficial. ${ }^{2}$

Why any new issues at all? Why not WTO business as usual? Why not just say no to new issues? ${ }^{3}$ I maintain that business as usual no longer is an option. The broad backlash against it is here to stay. There will be no results from multilateral negotiations this way, no chance to enjoy the new gains from global integration without some broadening of the beneficiary base beyond business as usual.

Why the WTO for my proposal - there are alternative forums and mechanisms? Part of my answer is that the WTO already oversees a market-supportive body of regulations; indeed that is its main purpose. Another part of my answer is that the WTO has already started implementing market-supportive new issues in the Trade-Related Intellectual Property Rights (TRIPs) Agreement, and in telecommunications and other services. The last part of my answer is that alternative forums have proved incapable of handling new issues effectively (e.g., the Organization for Economic Cooperation and Development on investment) and unable to broaden the constituency of beneficiaries (e.g., the North American Free Trade Area's failed attempt to draw in labor and environmental communities).

I begin below with a very brief discussion of what's to be gained in a new round of WTO negotiations. In Section 3, I describe what I mean by market-

\footnotetext{
${ }^{1}$ The conference paper by Schott describes recent non-momentum in the negotiations

2 In the language of labor negotiations, I am proposing integrative bargaining in restarting WTO negotiations; I am trying to avoid distributive bargaining. See Walton and McKersie (1965).

3 As recommended by, for example, a number of the chapters in Bhagwati (1998) or Bhagwati and Hudec (1996).
} 
supportive regulation, illustrating it in Sections 4, 5 , and 6 by competition, technology, and labor policies. I finish with brief discussions of how the WTO might practically incorporate the market-supportive new issues and why domestic political constituencies might come to support their incorporation into the WTO. ${ }^{4}$

\section{WHAT'S AT STAKE}

Traditional estimates of the gains from more trade liberalization are notoriously modest. ${ }^{5}$ But most traditional studies assume away striking gains that new research reveals. ${ }^{6}$ These non-traditional gains include effects on growth, technology, productivity, market power, and best-practice benchmarks (as well as tighter industry dispersion around these benchmarks). Much of this new research has been carried out at the industrial grass roots-firm-by-firm, establishment-by-establishment, shop-floor-by-shop-floor. Traditional ambiguities caused by over-aggregated measures have been reduced.

The new research suggests sizeable gains to further global liberalization, even for relatively open countries like the United States. These gains are of many kindsgains from trade in goods and services due to stronger export engagement and deeper import dependence, and from inward and outward investment and technology transfer.

Global integration of all kinds seems vital for superior economic performance. American workers, firms, and communities with lots of exports, imports, overseas licensing and supplier relationships, investment abroad, and foreign investment at home prosper compared to their insular counterparts.

There's still a lot at stake.

\section{MARKET-SUPPORTIVE REGULATION AND THE MARKET SYSTEM}

Market-supportive regulations are those that make the market system more effective, stable, and sustainable. But the terms in this brief statement need elaboration.

What is called the "market system" is a peculiar mix of competition and cooperation. Everyone is familiar with the competition. But few reflect very deeply on the cooperation. Almost all the agents that compete are social groupings, whose internal organization is for the most part cooperative, not competitive. "Firm" is the generic term for these agents-corporations, partnerships, labor unions, not-for-profits, and others.

Firms are both the suppliers of most products and services and also the principal buyers. Households, who also are cooperative social agents, are generally buyers only of final goods as consumers. These final goods are assembled from materials and components that have already been bought and sold many times by firms, through a long series of exchanges in both input markets and in internal, intrafirm transactions. The market system is a complex, vertical, and social network of purchases and sales, contracts and conventions among firms. The market system is itself a mix of competition and cooperation, a social organism. The quality of the organism's competition and cooperation determines how effectively and efficiently it combines fundamental inputs such as worker services to produce final goods and services for those very workers.

In simple terms, the quality of this social market system determines the standard of living of its workers.

So the prototypical "economic man/woman" so common in elementary textbooks is really a stylized fiction; so, too, the mythical individual entrepreneur. Typical real market transactions involve competition and cooperation in a complex sequence among internally cooperative social groups. The internal cooperation is governed by such regulations as company law; the external competition and cooperation by such regulations as contract law and competition (antitrust) policy. Many of the market's social groups have legal status that grants them the right to collectively own and exchange property, including intangible property (e.g., intellectual property) and licenses (e.g., to represent a set of workers), and to differentiate and isolate their legal liability as group members from their liability as individuals.

Thus, the market system is socially populated, socially rooted, socially conditioned, and socially constructed. It is far, far away from the chaotically competitive "law of the jungle" with which it is sometimes rhetorically confused.

I will argue that, correspondingly, a sustainable global market system will be socially constructed and conditioned, too, by policy design.

Economic regulations condition this competitive-cooperative market system. Among other goals,

\footnotetext{
${ }^{4}$ I intend to draft a more detailed defense of my thesis, to be published by the Institute for International economics.

${ }^{5}$ The conference paper by Hertel illustrates this point.

6 This new research is surveyed most directly in Richardson (2000) and Lewis and Richardson (2000).
} 
they aim to make the market system work better. Designed properly, they are market-supportive ${ }^{7}$ and part of the social infrastructure. ${ }^{8}$ They regulate the intensity of competition, the scope of cooperation, and define the due processes and legal boundaries for both, including the important boundary between coercive and voluntary transactions. For one example, company law supports the market for corporate control; it establishes categories of voting rights and procedures for shareholders, and determines when and how a rival firm's managers can compete for the shareholders' allegiance (cooperation). For a second example, labor-relations law supports the market for cooperative representation-agency; it establishes workplace voting procedures for workers to be represented collectively by a union and when and how another union could compete for certification to organize the workers cooperatively. For a third example, intellectual-property law aims to undergird the markets for artistic creation and productive innovation, indirectly compensating for externalities and for missing inter-generational markets.

Not all economic regulations are market-supportive. Some are market-inhibiting-though often "for a good cause" (e.g., prohibitions on markets in socially dangerous goods and services, or limitations on current markets to avoid extinction of future markets, as in fisheries regulation). Environmental regulations are often of this sort. Though I leave them outside my own set of illustrations of marketsupportive regulation, they need not be left out. In market-supportive variants, environmental regulations aim to create and refine markets - markets for spillovers that are otherwise nonmarketable (externalities), and markets for intergenerational transactions that are infeasible without devices to represent the preferences and objectives of the unborn. ${ }^{9}$

Still other regulations are distant from markets. Social regulation ${ }^{10}$ often is motivated by nonmaterial values and needs. Voting regulations, systems of education, criminal justice, national military service, and social-welfare and human-rights policies are all social regulations that are all less directly supportive of markets than the economic regulations above. Social regulations are important- vitally importantbut they are not promising issues for impending negotiations that should aim to realize the large gains from further integration of global markets. Social regulations are too distant, too diversionary, not sufficiently conformable, and orthogonal. ${ }^{11}$

I want to argue, in the rest of this paper, that three kinds of limited, market-supportive economic regulations are natural companions to global markets, enhancing their performance and broadening their legitimacy.

\section{MARKET-SUPPORTIVE COMPETITION POLICIES}

Market-supportive competition policies are one of the best examples of regulation that conforms to the fundamental purposes of the WTO and that belongs under its umbrella. Multilateral trade negotiations and competition policies usually have very similar objectives. The aim of both is more open market organization of economic activity. ${ }^{12}$ Openness connotes freedom of entry and contestability (defined below).

I believe that the time is ripe for multilateral WTO negotiations over "conditions of competition"though they will take a long time to reach fruition and must properly begin in a very modest, procedural way. In previous writings, Edward M. Graham and $\mathrm{I}^{13}$ have recommended that first-generation initiatives include only the gradual commitment of all WTO members to implementing a baseline set of domestic competition policies ${ }^{14}$ concerning cartel practices and anti-competitive horizontal restrictions,

\footnotetext{
${ }^{7}$ I do not mean to make this term coincident with "incentive compatible."

8 This "progressive" view of the way government regulation can support markets has deep roots in economic philosophy, the institutional school, and the social gospel, and surfaces frequently (Reich, 1991; World Bank, 1997; Holmes and Sunstein, 1999; for example), though generally submerged by alarmist, populist accounts of the war between greed and governance. Garrett (1998, pp. 789ff.), for example, describes the potential for a "virtuous circle between activist government and international openness."

${ }^{9}$ See Noll (1997) for further discussion. Esty (1994) is still the best treatise on how environmental regulations could be negotiated globally in a WTO-like GEO (Global Environmental Organization).

${ }^{10}$ See Noll (1997) for a recent articulation of the traditional distinction between social and economic regulation, along with a thoughtful discussion of the differing international implications of regulatory reform in the two cases.

${ }^{11}$ See Nivola (1997). Rodrik (1997), Ch. 5, by contrast, is willing to entertain careful inclusion of some social regulation in trade negotiations. He labels this the "social safeguards" approach.

${ }^{12}$ By contrast, bilateral and regional negotiations often have many other objectives, from coalition-building to regional security.

${ }^{13}$ See Richardson (1998a,b) and a series of papers brought together in Graham and Richardson (1997a,b). Other contributions include Graham (1994, 1995, 1996, 1998), Graham and Lawrence (1996), Graham and Richardson (1999), and Richardson (1995, 1997, 1999).

${ }^{14}$ The number of countries implementing a formal competition policy in recent years has risen sharply to almost 70: see UNCTAD (1997) and WTO (1997).
} 
and creating guidelines for merger and acquisition. These baseline policies would be notified to the WTO, which would also oversee a process of consultations, but initially not formal dispute settlement. To emphasize its modest, though market-supportive goals, we have characterized this phase as "cooperative unilateralism."

Only in a second phase did we imagine a commitment to negotiate a Trade-Related Antitrust Measures (TRAMs) Agreement and to bring normal dispute settlement to bear. The agenda for such second-phase negotiations is the same set of baseline practices as countries have taken on in the first phase, all aimed at "contestability." Contestability denotes the right to compete for market access by exporters, foreign investors (who would receive national treatment, with limited exceptions), and small and new home suppliers alike. ${ }^{15}$ These groups are the beneficiaries and constituents of the TRAMs Agreement that we foresee and recommend. ${ }^{16}$

Indeed Graham and I have argued that a "conditions-of-competition" WTO agenda is becoming more and more natural and increasingly necessary. The concerns and ambiance of trade negotiation and grievance are rapidly changing. Concessions that concern regulatory practice pervade recent negotiations over insurance, intellectual property, telecommunications services, and trade-related investment measures. Contentions over industrial policies lie ahead in financial services, information technology, electronic commerce, agriculture, and technology-related investment requirements. Fundamental disagreement about what government is and who its regulators represent will make bargaining over procurement and labor relations thorny. Chinese and Russian accession to the World Trade Organization - or not-will ultimately rest on bargaining over internal accessibility policies, not border measures.

Social conditions of competition are the common theme in all these new concerns and ambiance. Who may compete with whom? Or displace them, or absorb them? Under what contingencies? With what kinds of government support? ${ }^{17}$ Using what processes, technology, contractual practices, employment relations?

But why the WTO? An important reason is that WTO-sponsored liberalization in key sectors such as services, telecommunications, and information technology will be the principal proving ground for how contestable global markets really are. ${ }^{18} \mathrm{~A}$ second reason is that baseline competition-policy commitments by large, would-be members of the WTO, especially China and Russia, will solidify the organization; without such commitments, all the more traditional WTO conventions "at the border" will be undermined seriously by private practices behind it. (China, for example, does not even practice internal, inter-regional freedom of trade.) A third reason is that the adoption of core competition policies in all WTO members helps to ease each member's transition toward more open borders. Enhancing internal contestability helps rationalize a country's internal market structure, allowing the fittest firms to prosper, absorbing weaker firms, and thereby making it easier to cope with additional pressures from freer trade and investment. A fourth reason is that baseline competition policies protect an economy from the worst abuses of other policies that support markets by protecting technological property rights, policies to which we turn next.

\footnotetext{
${ }^{15}$ Contestability is not the same as market access, as usually described in trade negotiations. As a right to compete, contestability is more akin to the idea of market accessibility. The reason for these distinctions is that every conception of market access involves a measurement. Virtually every measurement of market access involves a market share or sales quota, anathema to antitrust and to the WTO. Undue focus on market access leads dangerously toward the capture of competition policy by industrial-policy advocates and other special interests. Wolff (1997, 1999), Howell (1998), and Wolff et al. (1998), for example, all conflate market access and accessibility. Antitrust specialists keep them distinct, for example in the counsel to "defend competition, but not any given competitors." Market accessibility can be evaluated by all the new antitrust tests of entry barriers and foreclosure: effects of anti-competitive practices on prices; on competition upstream, downstream, and in adjacent regions and products; on the sunk costs of entry; and on the range of desirable attributes of a product or service.

${ }^{16}$ Assuming satisfactory performance at this second stage, our third stage (TRAMs-plus) would extend the coverage to more controversial issues, including vertical practices and competition-policy safeguardsexemptions for industries that are downsizing The second and third stages of our proposal might be phased in at different rates by different member groups, as in the case of TRIPs.

${ }^{17}$ European practice includes such government support ("state aids") as a competition policy issue.

${ }^{18}$ The WTO is not the only multilateral forum in which integration of competition, trade, and investment policies could be pursued. Nevertheless, we conclude from our research, as does Brittan (1997) and Van Miert (1998), that the WTO is ideally poised to achieve the requisite capability. The TRIPs Agreement and those on financial services, basic telecommunications, and other services will inevitably change the character of WTO proceedings in the direction of professional and regulatory expertise and information-provision. This is exactly the direction of change necessary to undertake our proposals.
} 


\section{MARKET-SUPPORTIVE \\ TECHNOLOGY POLICIES}

Some market-supportive technology regulations already have been on the WTO negotiating table. Those protecting intellectual technological property have recently been rationalized and codified in the TRIPs (Trade-Related Intellectual Property) Agreement of the WTO. ${ }^{19}$ How successful has the experience been so far? How well does it support my thesis? Are there other market-supportive technology policies that belong in the small set that I would define as market-supportive. My answers to the first two questions, relying heavily on Maskus (2000a, 2000b), are "reasonably successful so far" and "reasonably strong support for my thesis." My answer to the third is that there is more to negotiate, especially in supporting the markets for distributing technology.

Like competition policies, market-supportive technology policies conform well to the fundamental purposes of the WTO. At a basic level, technology is information. $^{20}$ Reasonably complete, diffuse information is a precondition for markets to work well-effectively, fairly, with minimal discrimination. These three are virtually the same desiderata as the WTO pursues for global markets. Market-supportive information is the reason that the WTO insists on detailed, accurate notification of policies by every member country (an unsung requirement and benefit of membership).

Markets work anyway, of course, in environments with imperfect or asymmetric information. But, they don't necessarily work well. A large microeconomics literature has shown this over the past twenty years. Imperfectly informed markets sometimes waste resources; they sometimes leave capable buyers isolated (rationed by discrimination); they sometimes violate the market system's self-imposed limitation to voluntary, noncoercive transactions.

- Somewhat rhetorically, it is worth observing that even economists don't believe in the merits of the completely free market for used cars and homes when their sellers know all the problems and their buyers do not. Buyer protection regulation, compulsory warranties, and legislation against fraud all help those markets work better.

- Closer to home in this paper, few economists automatically defend the free market for genetically modified organisms, when at least some of them may be marketed by copy-cat or grey-market sellers who do not themselves know all the cautionary conditions and risks in producing and using such biotechnologies. This market, too, would work better with some sort of compulsory (global?) warranty and userprotection regulation.

The examples clearly suggest the awkwardness of calling uninformed "voluntary" transactions voluntary at all. And if "coercive" isn't quite the right word either, perhaps "exploitative" is, connoting the power of information advantage.

I believe that imperfectly informed markets need regulatory support before they can become properly defensible, and that this also is true globally.

The view that technology is basically information signals very clearly that technology is both a private good (an input), and a public good. Maskus (2000b, Ch. 3), for example, conceives of intellectual property rights (IPRs) as "fundamental inputs ... public inputs ... public infrastructural investments."

Identifying technological IPRs as distinctive private inputs is helpful for explaining why production and distribution of the technologies being protected is so important to the market system, qualitatively and quantitatively. ${ }^{21}$ Identifying IPRs as public inputs raises immediately the public-goods problem of whether markets generate enough production and enough distribution of technology. The traditional answers are: no, not enough production, as for any public good whose value is nondiminishable and whose exclusion devices are infeasible or prohibitively costly; ${ }^{22}$ and no, not enough distribution, because those exclusion devices that remain feasible to protect producers' incentives also screen out users whose valuation of the technology exceeds its marginal cost.

\footnotetext{
${ }^{19}$ I have in mind those parts of the TRIPs Agreement concerning patents, integrated circuits, and trade secrets (distinctive ways that a firm operates that have unique commercial value). The sections on copyrights and trademarks are less supportive of technology as I mean it.

${ }^{20}$ Technology-as-information is sometimes discernible in the details of a process innovation, other times in the physical details of a product innovation.

${ }^{21}$ Romer (1994) shows that the benefits (to a developing country, no less) from being able to import unique inputs, embodying new technology, are presumptively many times larger (20 times larger is his central calculation) than traditional calculations of the gains from trade. See also Lawrence and Weinstein (1999), who find evidence that imported inputs contributed importantly to Japanese and Korean productivity growth. See also Katz (1987)

${ }^{22}$ Nondiminishability means that one agent's use does not reduce the amount of information left over for other agents to use. Nonexcludability is the extreme property that makes it impossible to isolate agents who are unwilling to contribute to paying for the new information.
} 
Policies and institutions that best support markets for technological innovation are controversial. ${ }^{23}$ They are controversial when private goods alone are in question. They are even more controversial for public goods. But simple intuition helps inform the controversy. The intuition is that because public goods have uniquely nondiminishable and nonexcludable properties, policies for supporting distribution markets will have even greater importance relative to production markets than for private goods. Encouraging extra distribution that is compensated at (marginal) cost creates no extra scarcity, and rations no unlucky users.

With respect to intellectual property itself, I believe the time is ripe for significant, balance-oriented refinement of the TRIPs Agreement. My general reading is that the existing agreement is a good start at supporting the market for producing new information, new ideas, and new technologies, but that ongoing TRIPs negotiations should more strongly support the market for distribution. The existing TRIPs Agreement has focused more on generation than dissemination, more on supporting the market to produce innovation and less on supporting the business-to-business "retail market" for technology users and traders. The two markets are very different, the agents (constituents) involved are very different, just as they are for electricity generation and distribution. ${ }^{24}$

Suppose that one grants that the technology distribution goal is clear and market-supportive. Still, the best practical sequence of steps to approach this goal is controversial. This suggests again a cautious, multistage negotiation. Caution might feature standstill on certain unfinished technology-production issues and experimentation on selected technology-distribution issues. In addition to TRIPs, several elements of experimentation might involve the WTO's Trade-Related Investment Measures (TRIMs) Agreement.

Specifically, I propose two families of marketsupportive TRIPs and TRIMs modifications: market facilitation measures and forbearance/standstill on controversial carry-over issues.

1. Facilitation. There has been little formalization of the technical and financial assistance provision of the TRIPs Agreement (Part VII). New adopters of TRIPs regimens have been loathe to pay their own administrative set-up costs, especially when short-term forecasts have these countries together paying out up to $\$ 5$ billion annually in royalties and fees to IP-abundant countries. ${ }^{25}$ Estimates of administrative costs are surprisingly low, however - roughly \$1 million/year for Bangladesh, Chile, Egypt (Maskus, 2000b, Ch. 4). A marketsupportive way to cover up-front administrative fixed costs is to finance them by loans. The loans could then be serviced out of transitional facilitation fees on cross-border royalties paid for hostcountry IP protection. ${ }^{26}$ Such an arrangement facilitates and finances mutually beneficial technical assistance. It is not foreign aid. It should be conceived as rent-reinvestment rather than rent-shifting. It could be tactically implemented by Patent Offices and by public-private consortia, rather than by diplomatic agencies. It would create natural forums for negotiating licensing and follow-on innovation, which aid in both the production and distribution of technology.

2. Forbearance. The current TRIPs Agreement preserves a great deal of national discretion (sovereignty). For example, there is national discretion on implementation definitions and procedures, ${ }^{27}$ publishing conventions for patents, exemptions (e.g., for plant breeding, health-related and other noncommercial research, environmental and species preservation, noncommercial use), and treatment of parallel imports. Parallel imports are "goods brought into a country without the authorization of the patent, trademark, or copyright holder after those goods were placed legitimately into circulation elsewhere" (Maskus, 2000b, Ch. 4). ${ }^{28}$

\footnotetext{
${ }^{23}$ Answers for tangible goods always have differed from answers for creative and artistic services (patents vs. copyright, for example, or bio-patents vs. others). "Best" is sometimes identified with notions of "dynamic efficiency."

${ }^{24}$ See a discussion of similar issues in electricity regulation in the Economic Report of the President (1999), Ch. 5, pp. 211-18.

${ }^{25}$ Maskus (2000b), Table 4.2, citing work by McCalman (1999). These can be construed as short-run profit transfers in light of Smith's (1999) findings that the enhanced market-power of IP owners, which distorts markets, dominates the market-expansion effects of stronger IP protection and the cost-savings from reduced anti-piracy with respect to U.S. trade.

${ }^{26}$ Such a fee would be essentially a temporary tariff, possibly degressive on services' imports of IP. Tariff revenues would service the loans that financed the implementation of TRIPs in the importing country.

${ }^{27}$ Article 31 of the TRIPs Agreement leaves countries discretion to set "working requirements" (Maskus, 2000b, Ch. 4; Watal, 1998).

${ }^{28}$ Virtually no poorer countries regulate parallel imports. This allows them as pure buyers to "shop for technology" from the cheapest source. The United States, as an important technology producer, restricts parallel imports to preserve the appropriate dynamic incentive (reward) for U.S. innovators. The European Union adopts a halfway house between innovation incentives and free trade, banning parallel imports from outside its membership, but allowing them from within for the sake of the "single market."
} 
Such discretion has surprising market value in cultures and environments where the very idea of property rights to technology is new. It allows experimentation with different standards and regulatory competition among them, in essence "innovation" in the procedures of IP protection. Considerations like these suggest the value of regularizing such status-quo discretion, at least for a time, rather than pushing ahead with deeper, tighter TRIPs commitments along the technology-production lines emphasized in the existing TRIPs Agreement. ${ }^{29}$

Technology aspects of the current TRIMs Agreement also might benefit from the preservation of national discretion (sovereignty). In particular, technology-transfer performance requirements on inward investors were not banned by the TRIMs Agreement. ${ }^{30}$ Preserving a country's ability to require technology transfer by inward investors-a ban on any future TRIMs ban-arguably is supportive of the market for distributing technology. ${ }^{31}$ Unlike other performance requirements, these may pay off in host countries. ${ }^{32}$ Among other reasons, technology transfer performance requirements force commercial negotiations over licensing, without dictating its terms. Otherwise anti-competitive, anti-market "refusal to deal" can become entrenched. Many technologies are, in essence, akin to essential facilities in the competition policies that govern transportation and telecommunications markets. ${ }^{33}$ And in such cases "negotiated compulsion" is a familiar tool of competition authorities (e.g., compulsory divestiture, cease-anddesist orders, consent decrees over licensing ${ }^{34}$ ) and of buyer-protection agencies (e.g., compulsory warranties, truth in advertising).

But why the WTO? The most obvious reason is that the WTO already has committed to incorporating technology policies, not only in TRIPs and TRIMs, but also in the two negotiated Information Technology Agreements, and maybe in coming E-commerce protocols. A less obvious reason is that if the WTO gradually incorporates a subset competition policy commitments, then it almost surely has to refine its technology agreements. Perspective and practice on how competition policies need to be different, if at all, for technology-intensive activities, is still being worked out. ${ }^{35}$ But the frontier of critical thinking in this area is clearly the tension between protecting the incentives to innovate and encouraging the distribution of its fruits. A final, but no less important reason, is that by undertaking technology commitments along the distribution-oriented lines sketched above, the WTO pulls technology users into the group of beneficiaries from global integration and broadens its support base beyond the usual well-heeled suspects!

\section{MARKET-SUPPORTIVE LABOR POLICIES}

WTO agreement on market-supportive labor regulations is the most radical-and the most speculative-aspect of my thesis. It would encompass only a subset of the familiar core labor principles, specifically those concerning freedom of association and collective bargaining. ${ }^{36}$ It belongs in the WTO because it is basically a proposal for liberalization of trade in services-worker agency servicesthe market services of agency that worker organ-

\footnotetext{
${ }^{29}$ The one exception to such discretionary forbearance might be a distribution-encouraging agreement disciplining parallel imports of public-health-related products and technologies, as endorsed by Maskus (2000a, 2000b). Such an agreement would allow some international price discrimination in relevant pharmaceuticals and related products, and discipline the arbitrage that sometimes undermines it. Lower prices in poor countries with significant public health needs would be offset by higher prices in richer countries. The result would be to support and expand markets to include users willing/able to pay only the marginal cost of public-health-related goods.

${ }^{30}$ It banned performance requirements covering compulsory local content and trade-balancing and foreign-exchange-balancing requirements (Schott and Burman, 1994, pp. 112-13)

${ }^{31}$ As a technology-production parallel and precedent, the WTO's Subsidies Code does not discipline research and development subsidies as harshly as it disciplines other subsidies.

${ }^{32}$ Moran $(1998,2000)$ argues persuasively that investor performance requirements for local content or joint ventures actually inhibit the global dissemination of technology. He also is critical of export and technology-transfer requirements, but not as persuasively. Export performance requirements, in fact, often serve as internal host-country antidotes to foreign investors negotiating exclusive, privileged, anti-competitive local market power (e.g., exclusive rights to supply).

${ }^{33}$ See Hausman and Sidak (1999) for a recent treatment of the related idea that mandated unbundling of the different elements of a telecommunications network is pro-competitive. Process technologies especially often can be unbundled from other productive inputs and sold separately (licensed out)

${ }^{34}$ For example, the U.S. Federal Trade Commission recently negotiated a consent decree with Ciba-Geigy and Sandoz in which they agreed to license technology and patents to a viable rival (with compensation) as a condition of FTC approval of their merger (Economic Report of the President, 1999, pp. 180-81).

${ }^{35}$ Gilbert and Shapiro (1997) and Economic Report of the President, (1999), Ch. 5.

${ }^{36}$ Likewise an American authorization of fast track might include only those market-supportive principles, not the longer list.
} 
izations and labor unions ideally provide. ${ }^{37}$ It therefore falls sensibly under the rubric of the General Agreement on Trade in Services (GATS). Under my proposal, the International Labor Organization would remain the forum for discussion of and commitment to broader labor-market principles.

In Elliott and Richardson (2001), my colleague Kim Elliott and I evaluate, then endorse, open trade in worker agency services. We see it as entirely conformable to the WTO's endorsement of open trade in other services. We understand such worker agency services to encompass primarily:

- Collective representation and bargaining over wages, benefits, and working conditions;

- Workplace safety monitoring;

- Grievance and dispute settlement;

- Training, apprenticeship, and employee assistance;

- Financial counsel (e.g., for pensions) and management of other benefits (e.g., child care).

We emphasize the market-supportive character of these services because they:

- Alleviate market failures associated with collective action problems, workplace public goods, ${ }^{38}$ imperfect information, and relationship-specific assets (relationship-specific assets are essentially what a firm's incumbent workers provide); ${ }^{39}$

- Discipline practices that border on coercion (recall that the market system pre-supposes voluntarism) ${ }^{40}$

- Create countervailing market power to the anti-competitive market power of firms.

When entry and accessibility are present, that is, when alternative local and global suppliers can contest the right to represent workers as agents, they perfect the market for such services. They enhance their quality and variety, encourage innovation in worker agency services, and lower their cost.

We foresee the same sort of gains from trade in worker agency services as exist for other agency services. Trade in accounting and legal services provides agency for users of information about firms (e.g., investors in them). Trade in distribution services provides enhanced agency for producers. Trade in brokerage and underwriting provides enhanced agency for borrowers, entrepreneurs, and innovators.

To be more precise, after a "cooperatively unilateral" first stage, we envision a Trade-related Worker Agency Services (TWAS) Agreement covering freedom of association and the right to collective bargaining, including designated activities and/or sectors in which national treatment would be offered to foreign worker organizations. Only after sufficient success in implementing this second stage would we propose widely cross-sectoral rights of establishment and national treatment for foreign worker organizations, subject only to negotiated exceptions. ${ }^{41}$

In the "cooperatively unilateral" first stage, national discretion would be virtually unaffectedsubject only to the commitment to implement baseline freedom of association and collective-bargaining, to notify these commitments to the WTO as well as the ITO, and to submit to the kind of (nonbinding) mediation, not dispute settlement featured above in the first phase of market-supportive competition-policy commitments. Formal dispute settlement would be introduced only in the secondstage TWAS Agreement, which would be modeled on services commitments under the GATS.

Restricting multilateral labor codes to just these market-supportive aspects-freedom of association

\footnotetext{
${ }^{37}$ See, for example, Stiglitz (2000), Part II. Pencavel (1991) is the most comprehensive treatment I know of labor unions as agents for their worker/principals, though he restricts his attention only to their wage, hours, and employment effects. See also Freeman and Medoff (1984) and Freeman and Kleiner (1990).

${ }^{38}$ Workplace public goods are defined by Pencavel (1991, p. 6) as the unwritten rules and conventions that are too costly to write down in detail, and that benefit workers (and often employers) in a nonexcludable, nonrival way.

${ }^{39} \mathrm{C}$ value of whatever assets the contracting agents bring to the relationship. But once negotiated, contracts may be costly to break. In that case there is an incentive created for each agent, through opportunistic behavior, to tilt the distribution of the extra value in their favor This is called the "hold-up" problem. Such opportunism, almost always present in contracts covering relation-specific assets, is more than a distributional question; it causes inefficiency in the form of under-investment in all relation-specific assets, including the employment relationship. On the general issues, see, for example Besanko, Dranove, and Shanley (1996), pp. 110-21. On their application to employment relationships, see Stiglitz (2000), pp. 16 passim.

${ }^{40}$ For example, freedom of association and collective bargaining automatically define and discipline some forms of forced labor. (They also will typically mitigate some forms of employment discrimination, such as age-ism). Other forms of coerced labor may be more effectively approached by ILO/WTO-coordinated negotiation, however, such as coercive child labor, which might best be conceived as parallel to the WTO's existing Article XXe discretion to block trade in goods made by prison labor

${ }^{41}$ We imagine such rights of establishment and national treatment to be broad, but not completely unconditioned.
} 
and collective bargaining-leaves a great deal of scope for both distinctive national labor-relations law and for ILO initiatives to set and publicize bestpractice standards. Countries would have considerable flexibility, especially in the first stage, to regulate the locus of collective bargaining (plant, firm, industry, country); to determine conditions for strikes (sectoral restrictions, arbitration/mediation rules, worker-replacement strictures, etc.). It also leaves scope for subsequent extension to labor issues that are more social than market-supportive, such as regulation of permissible working hours and ages and discrimination.

Our vision inevitably involves more than the traditional amount of competition among unions, and opens labor relations to cross-border competition, too. But, it does not disparage traditional worker solidarity. In fact, it emphasizes the fact that some unions serve their combined membership better than others (with fewer internal inefficiencies or political diversions, and less corruption). It also emphasizes global worker solidarity-similar workers worldwide can collectively and globally modulate the competition among themselves in the same way that unionized workers in a single plant or firm do.

But why the WTO? The most important reason is that our proposed arrangements for trade in worker agency services are market supportive, marketopening, and indistinguishable from GATS protocols for other services. They open trade in labor agency services to new entrants (incumbents already include expert consultancies, temporary-labor firms, construction companies, and so on) - specifically to traditional unions who are rethinking their objectives and economic roles under the heading "new unionism." Finally, certain familiar issues in labor relations such as contract compliance and certification/decertification have natural analogs in competition policy. We envision that a WTO competition-policy agreement could in at least several aspects be tailored to protect open and transparent competition to represent workers.

Critics, of course, will have much to say about the detail of this proposal. But they may have even more to say about its apparent fundamental weakness. "Unions just aren't like that." My answer is, "Maybe some are not, but they should be." Labor unions admittedly depart from market-supportive ideals, but so do firms. Mundane political objectives of labor unions can often conflict with market objectives (wages, benefits, working conditions), but mundane political objectives of firms similarly compete with their market objectives. ${ }^{42}$ Labor unions can be undemocratic, but so can firms (e.g., in voting vs. nonvoting shares and in rights of minority shareholders). Labor unions can be corrupt, but so can firms. ${ }^{43}$

\section{WHERE THE LOCAL POLITICAL SUPPORT LIES}

In democracies, no good idea is ever adopted without political support. Where would local political support come from for the thesis of this paper, were it to be deemed a "good" idea? At first, the answer seems to vary with a country's standard of living.

Where would the local political support come from in richer countries?

Not from the usual suspects. That would be looking for love in all the wrong places. The traditional private-sector trade community is skeptical about global competition policies, lukewarm toward information dissemination, and downright opposed to the global adoption of any core labor rights. At least for the moment ....

- But, small business ought to recognize the value of baseline competition-policy protection in foreign markets.

- But, educators and farmers and hospitals ought to recognize the value of baseline policies that facilitate distribution of technology.

- But, workers and their unions ought to recognize the value of multilateral support for the global association and bargaining rights that put them on the same footing as corporate owners of tangible and intellectual property rights.

- And, if small businesses, socially-oriented agencies, workers, and unions are not seeing any significant gains for themselves from further globalization of the traditional, naked kind, can anyone really blame them for thinking that

\footnotetext{
${ }^{42}$ See Pencavel (1998), pp. 30-40. For example, firms, like unions, can divert enormous resources from market activities to support political parties, candidates, and regulatory agencies whose decisions will guarantee the firms political access and political security. See Grossman and Helpman (1994). For an account of labor agents' potential constructive political role in modulating globalization, deregulation, and reform, see Freeman (1993), Section III and Stiglitz (2000), Part III.

${ }^{43}$ And unions, in several well-publicized cases (e.g., Poland), have been strong promoters of democracy, which in turn disciplines corruption (Elliott (1997)) and supports markets.
} 
multilateral liberalization serves only the profitminded, capitalist owners of big business?

And where would the local political support come from in poorer countries?

Not from corrupt elites. They will realize that their power is undermined by open markets-open markets that are sought by competition policy and that are enhanced by worker-oriented competition among unions and other labor agents. They will realize that their power also is undermined by the security of all kinds of property rights, including those to develop and fairly apply innovation and those to represent workers collectively.

But honest firms, and honest unions, and technology users - no matter how poor - are all potential gainers from these initiatives.

So perhaps the answer to where the local political support lies does not vary across countries after all. Perhaps it can be summarized very crisply. Everywhere it comes from the "margin"-the margin of persons and groups on the outer edge of gains from the narrow, naked globalization of commerce alone. If, by contrast, the market system - as I have described it-is what is on the WTO's negotiating table, are there not gains for large masses? And as long as regulations are what I have called marketsupportive, might not even commercial interests end up gaining, too, after all?

Surely there's more promise in positive WTObased momentum than the trickle-down of rising tides, either within a country or among them!

\section{CONCLUSION}

I am persuaded that the WTO's incorporation of a limited set of market-supportive new issues would unleash large mutual gains to a broad constituency of businesses, worker groups, and others, and clear the way for more legitimate and more sweeping global market integration in the new millennium.

And to be completely clear about it, my proposal for sequentially embodying market-supportive new issues in the coming WTO negotiations is different from two others that aim at somewhat the same outcome. One is the stance of real politiqueconcede new issues to buy off the opponents of further global integration-"feed the trade sharks" as one commentator put it. ${ }^{44}$ The second is the populist stance of stakeholder economics, that somehow everyone has a civil or human right to voice or ownership in market institutions - therefore, new constituencies have a natural democratic right to be at the commercial negotiating table with their new issues.

My problem with the first is that it is too crass, and yields too quickly to the near-zero-sum practice of tossing lesser bones to rival dogs. My problem with the second is its fundamental misunderstanding of both democracy and the way that it has made itself prosperous by ceding conditional and exclusionary property rights to social market institutions.

\section{REFERENCES}

Besanko, David, David Dranove, and Mark Shanley. The Economics of Strategy, New York: John Wiley, 1996.

Bhagwati, Jagdish. A Stream of Windows: Unsettling Reflections on Trade, Immigration, and Democracy, MIT Press, 1998.

and Robert E. Hudec. Fair Trade and Harmonization: Prerequisites for Free Trade?, Volumes 1 and 2, MIT Press, 1996.

Brittan, Sir Leon. "Competition Policy and the Trading System: Towards International Rules in the WTO," manuscript, remarks given for the Institute for International Economics, Washington, D.C., November 20, 1997.

Destler, I. M., and Peter J. Balint. "The New Politics of American Trade: Trade, Labor, and the Environment," Washington, D.C.: Institute for International Economics, Policy Analyses No. 58, October 1999.

Elliott, Kimberly Ann, ed., Corruption and the Global Economy. Washington, DC: Institute for International Economics, 1997.

and J. David Richardson. "Free Trade in Worker Agency Services.” Washington, DC: Institute for International Economics, in process, 2001.

Esty, Daniel C. Greening the GATT: Trade, Environment, and the Future, Washington, DC: Institute for International Economics, 1994.

Freeman, Richard B. "Labor Market Institutions and Policies: Help or Hindrance to Economic Development," in Proceedings of the World Bank Annual Conference on Development Economics 1992, Lawrence H. Summers, Shekhar Shah, eds., World Bank, 1993, pp. 117-44. and Morris M. Kleiner. "The Impact of New Unionization on Wages and Working Conditions," Journal of Labor Economics (January 1990), pp. S8-25. , and James L. Medoff. What Do Unions Do? New York: Basic Books, 1984.

\footnotetext{
${ }^{44}$ Stokes (1999). See also Destler and Balint (1999) and Wright (2000), for more extensive proposals apparently motivated by real politique.
} 
Garrett, Geoffrey. "Global Markets and National Politics: Collision Course or Virtuous Circle?," International Organization (Autumn 1998), pp. 787-824.

Feketekuty, Geza, and Bruce Stokes. Trade Strategies for a New Era: Ensuring U.S. Leadership in a Global Economy, New York: Council on Foreign Relations, 1998.

Gilbert, Richard, and Carl Shapiro. "Antitrust Issues in the Licensing of Intellectual Property: The Nine No-No's Meet the Nineties," Brookings Papers on Economic Activity: Microeconomics, 1997, pp. 283-336.

Graham, Edward M. "U.S. Antitrust Laws and Market Access to Japan," in Unilateral Application of Antitrust and Trade Laws: Toward a New Economic Relationship between the United States and Japan, Henry B. Cortesi, ed., New York: The Pacific Institute/The Asia Institute, 1994.

"Competition Policy and the New Trade Agenda," in New Dimensions of Market Access in a Globalizing World Economy, Organization for Economic Cooperation and Development, Chapter 12, 1995.

"Competition Policy in the United States," in Competition Regulation Within the APEC Region: Commonality and Divergence, Carl J. Green and Douglas E. Rosenthal, eds., New York: Oceana Press, 1996.

"Contestability, Competition, and Investment in the New World Trade Order," in. Trade Strategies for a New Era: Ensuring U.S. Leadership in a Global Economy, Geza Feketekuty and Bruce Stokes, eds., New York: Council on Foreign Relations, 1998.

, and Robert Z. Lawrence. "Measuring the International Contestability of Markets: A Conceptual Approach," Journal of World Trade (October 1996), pp. 5-20.

, and J. David Richardson. "Competition Policies for the Global Economy,” Washington, D.C.: Institute for International Economics Policy Analyses No. 51, November 1997a.

and eds., Global Competition Policies, Washington, D.C.: Institute for International Economics, $1997 \mathrm{~b}$.

and "A U.S.-E.U. Road Toward Multilateralism in International Competition Policy," Economic Perspectives (February 1999), the United States Information Agency, pp. 27-29.

Grossman, Gene M., and Elhanan Helpman. "Protection for Sale," American Economic Review (September 1994). pp. 833-50.

Hausman, Jerry, and J. Gregory Sidak. "A Consumer-Welfare Approach to the Mandatory Unbundling of Telecommunications Networks," manuscript, 1999.

Holmes, Stephen, and Cass R. Sunstein. The Cost of Rights: Why Liberty Depends on Taxes. New York: W.W. Norton, 1999.
Howell, Thomas R. "The Trade Remedies: A U.S. Perspective," in Trade Strategies for a New Era: Ensuring U.S. Leadership in a Global Economy, Geza Feketekuty and Bruce Stokes, New York: Council on Foreign Relations, 1998.

Katz, Michael L. "The Welfare Effects of Third-Degree Price Discrimination in Intermediate Good Markets," American Economic Review (March 1987), pp. 154-67.

Lawrence, Robert Z., and David E. Weinstein. "Trade and Growth: Import-Led or Export-Led? Evidence from Japan and Korea," National Bureau of Economic Research Working Paper No. 7264, July 1999.

Lewis, Howard, and J. David Richardson. Why Global Integration Matters Most! Washington, DC: Institute for International Economics, 2000.

Maskus, Keith E. "Intellectual Property Issues for the New Round," in The WTO After Seattle, Jeffrey J. Schott, ed., Washington D.C.: Institute for International Economics, forthcoming, 2000a.

International Protection of Intellectual Property Rights: Evidence, Analysis, and Policy, Washington, D.C.: Institute for International Economics, forthcoming, $2000 \mathrm{~b}$.

McCalman, Philip. "Reaping What You Sow: An Empirical Analysis of International Patent Harmonization," Australian National University Working Paper in Economics and Econometrics 374, 1999.

Moran, Theodore H. Foreign Direct Investment and Development: The New Policy Agenda for Developing Countries and Economies in Transition. Washington, DC: Institute for International Economics, December 1998.

"A New Paradigm: Foreign Direct Investment and Development," in forthcoming volume in memory of Raymond Vernon, 2000.

Nivola, Pietro S., ed. Comparative Disadvantages? Social Regulations and the Global Economy, Washington, DC: The Brookings Institution Press, 1997.

Noll, Roger G. "Internationalizing Regulatory Reform," in Comparative Disadvantages? Social Regulations and the Global Economy, Pietro S. Nivola, ed., Washington, DC: The Brookings Institution Press, 1997.

Pencavel, John. Labor Markets Under Trade Unionism: Employment, Wages, and Hours. Blackwell, 1991. "The Appropriate Design of Collective Bargaining Systems: Learning From the Experience of Britain, Australia, and New Zealand," manuscript, November 1998, forthcoming in Comparative Labor Law and Policy Journal.

Reich, Robert B. The Work of Nations: Preparing Ourselves for 21st-Century Capitalism, New York: Alfred A. Knopf, 1991.

Richardson, J. David. Comment on J. Michael Finger, “Can Dispute Settlement Contribute to an International Agreement (Institutional Order) on Locational Competition?," in Locational Competition in the World Economy, Horst Siebert, ed., Symposium 1994, The Kiel Institute, 1995. 
"Competition Policies as Irritants to Asia-Pacific Trade," in East Asian Trade After the Uruguay Round, David Robertson, ed., Cambridge University Press, 1997.

"The Coming Competition Policy Agenda in the WTO," in Launching New Global Trade Talks: An Action Agenda, Jeffrey J. Schott, ed., Washington, DC: Institute for International Economics, 1998a.

"Multilateralizing Competition Policy Conventions," Trade Policy Forum on Private Practices and Trade Policy, Washington, DC. Brookings Institution, 1998b.

"A Cooperative Unilateral Road Toward Multilateralism in International Competition Policy," United States Department Of Justice, 1999.

.Exports Matter...And So Does Trade Finance," in Ex-im Bank in the 21st Century: A New Approach? Gary C. Hufbauer and Rita M. Rodriguez, eds., Washington D.C.: Institute for International Economics, forthcoming, 2000.

Rodrik, Dani. Has Globalization Gone Too Far? Washington, DC: Institute for International Economics, 1997.

Romer, Paul. "New Goods, Old Theory, and the Welfare Costs of Trade Restrictions," Journal of Development Economics (February 1994), pp. 5-38.

Schott, Jeffrey J. and Johanna Buurman. The Uruguay Round: An Assessment, Washington, D.C.: Institute for International Economics, 1994.

Smith, Pamela J. "Are Weak Patent Rights a Barrier to U.S. Exports?” Journal of International Economics (June 1999), pp. 151-77.

Stiglitz, Joseph. "Development Strategies and the Labor Market," Keynote Address to the Industrial Relations Research association, Massachusetts, manuscript, 2000.

Stokes, Bruce. "Feeding the Trade Sharks," National Journal (July 24, 1999), p. 2180.

United Nations Conference on Trade and Development. World Investment Report 1997: Transnational Corporations, Market Structure, and Competition Policy, United Nations, 1997.

U.S. Council of Economic Advisers, Economic Report of the President, Washington, D.C, 1999.

Van Miert, Karel. "The WTO and Competition Policy: the Need to Consider Negotiations," manuscript, Geneva, April 21, 1998.

Walton, Richard E., and Robert B. McKersie. A Behavioral Theory of Labor Negotiations: An Analysis of a Social Interation System, New York: McGraw-Hill, 1965.

Watal, Jayashree. "Pharmaceuticals Patents, Prices, and Welfare Losses: A Simulation Study of Policy Options for India Under the WTO TRIPs Agreement," Manuscript, 1998.
Wolff, Alan Wm. "Trade and Competition Policy," manuscript, remarks given for the Economic Strategy Institute, Washington, D.C., December 15, 1997.

"Unanswered Questions: The Place of Trade and Competition Policy in the 'Seattle Round," manuscript delivered at the OECD Conference on Trade and Competition, June 30, 1999.

Thomas R. Howell, and John R. Magnus. "Trade and Competition Policy: A Suggested U.S. Strategy," manuscript, November 4, 1998.

World Bank. The State in a Changing World. Washington, DC: World Development Report, 1997.

Wright, Robert. "Continental Drift," The New Republic, January 17, 2000, pp. 18-23.

World Trade Organization. "Trade and Competition Policy," in Annual Report 1997, Vol. 2, 1997. 